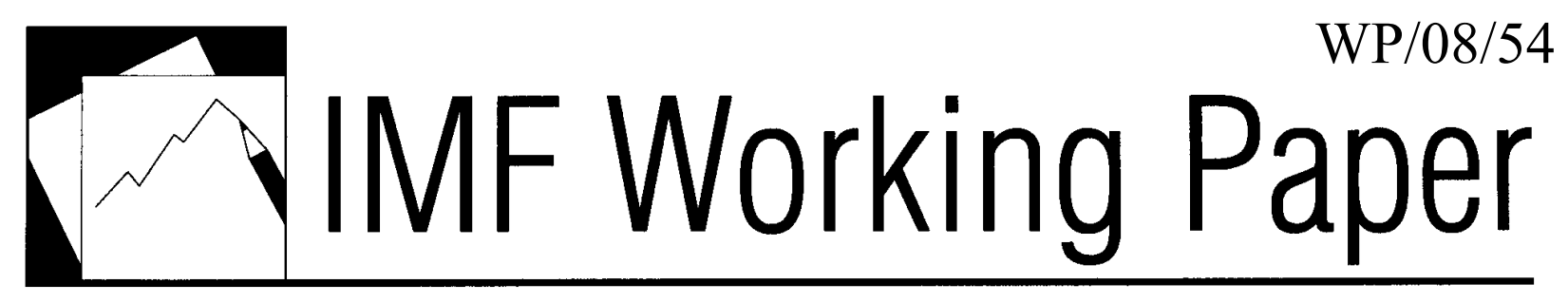

\title{
India: Is the Rising Tide Lifting All Boats?
}

\author{
Petia Topalova
}





\title{
IMF Working Paper
}

\author{
Asia and Pacific Department
}

\section{India: Is the Rising Tide Lifting All Boats? \\ Prepared by Petia Topalova ${ }^{1}$}

Authorized for distribution by Charles Kramer

March 2008

\begin{abstract}

\section{This Working Paper should not be reported as representing the views of the IMF.} The views expressed in this Working Paper are those of the author(s) and do not necessarily represent those of the IMF or IMF policy. Working Papers describe research in progress by the author(s) and are published to elicit comments and to further debate.
\end{abstract}

While many have celebrated India's accelerating economic growth, some have expressed concern about the distributional impacts of the growth process. Cognizant of the vulnerability of its large population in poverty, India's authorities have made faster and more inclusive economic growth the primary goal of their development strategy. This paper aims to document how the benefits of economic expansion were shared across the income distribution over the last two decades using disaggregate household level data. Experiences across Indian states suggest an important role for economic policy in shaping the inclusiveness of growth. States with higher financial development, more flexible labor markets, and higher average education experienced greater relative gains for the poor. Improving infrastructure may also lead to a growth process that is more inclusive of the poor.

JEL Classification Numbers: O12, O43, D31

Keywords: Poverty, inequality, inclusive growth, India

Author’s E-Mail Address:ptopalova@imf.org

\footnotetext{
${ }^{1}$ The author would like to thank Catriona Purfield for sharing her data on state-level indicators, and Shawn Cole, Kalpana Kochhar, Charles Kramer, and Arvind Subramanian for useful discussions and assistance.
} 


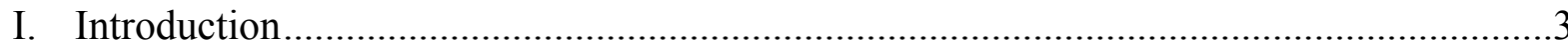

II. Growth, Poverty, and Inequality in the Last Two Decades .................................................

A. Growth and Poverty …………..........................................................................

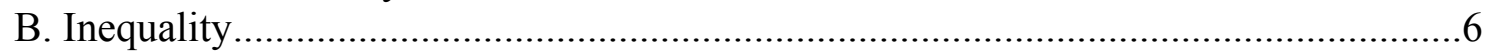

C. Decomposing Poverty Reduction.......................................................................

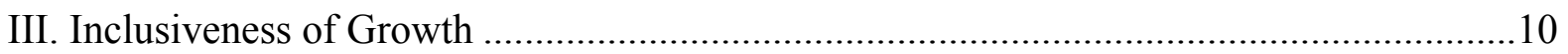

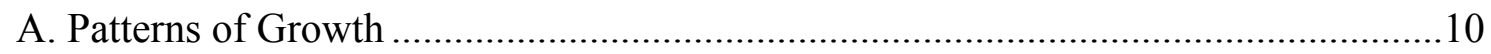

B. Quantifying Growth Inclusiveness ........................................................................14

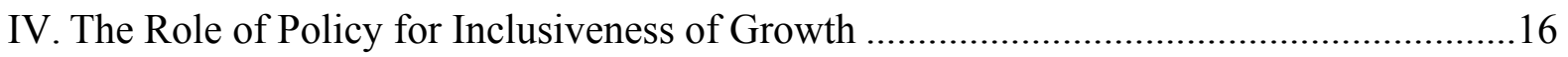

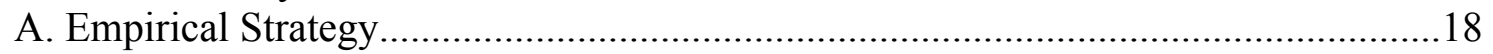

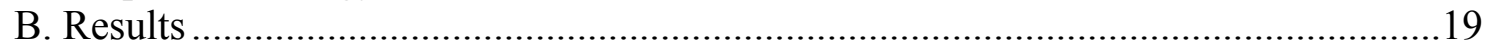

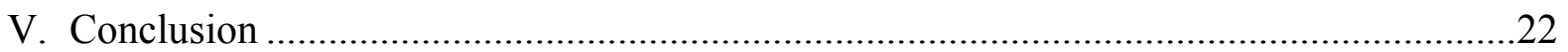

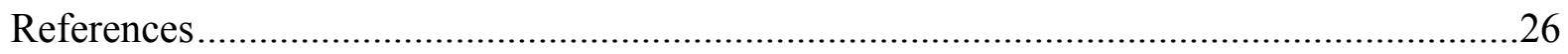

Figures

1. Poverty and Inequality Across Indian States ……........................................................

2. India: Patterns of Real Consumption Growth ................................................................11

3. Real Consumption Growth of the Top and Bottom 30 Percentile of the Population

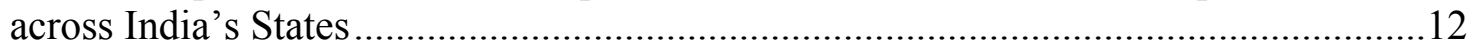

4. India: Patterns of Real Wage Growth .........................................................................

5. Growth Rates of Average Per Capita Consumption According to Characteristics

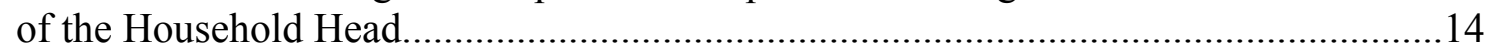

Tables

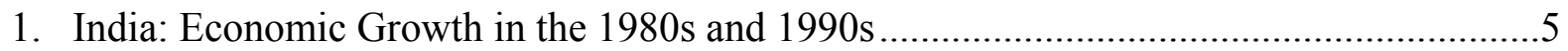

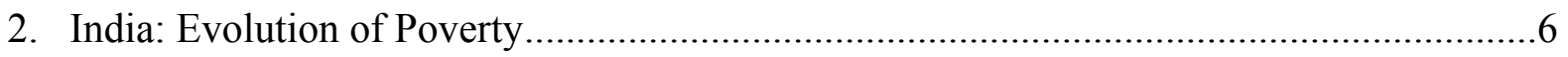

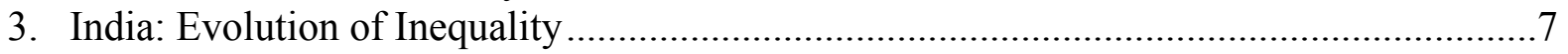

4. India: Decomposing Changes in Poverty ....................................................................

5. Growth Inclusiveness and Sectoral Composition of Growth...........................................15

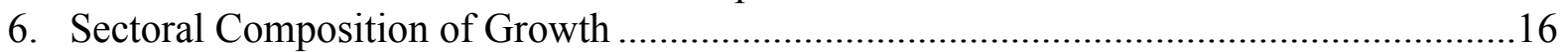

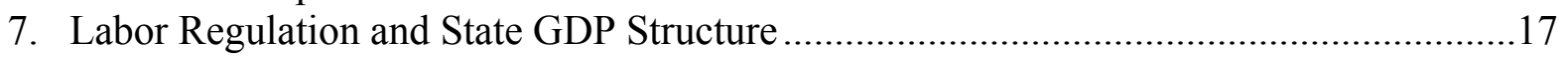

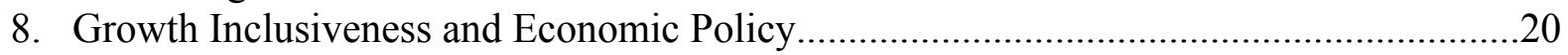

Appendix

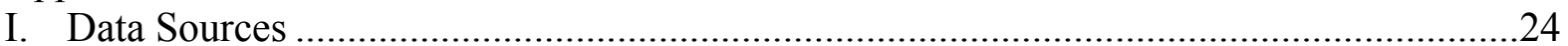




\section{INTRODUCTION}

India is enjoying a period of unprecedented growth. For the past four fiscal years, real GDP has risen at over 8.5 percent per year, making India one of the world's fastest growing economies. Yet, India still has the largest concentration of poor people in the world. The extent to which India's poor have been able to take up the opportunities provided by an expanding economy, and contribute to its continuing expansion is an important question for the well-being of millions. It is also at the heart of the current political debate in India. Decisive reforms are required to ensure continuing economic growth, yet the ability of the government to pass and sustain reform momentum depends on popular support. If large parts of the populations are left behind, even if only in relative terms, the viability of future reforms may be threatened. ${ }^{2}$ Cognizant of this, authorities have made "inclusive growth" a key element of their policy platform, stating as a goal: "Achieving a growth process in which people in different walks in life.... feel that they too benefit significantly from the process." (Alhuwalia, 2007)

While inclusive growth has become a prime policy issue in India, relatively little work has examined how inclusive past growth has actually been, or whether the new pro-business paradigm has affected the distribution of economic gains. Research has been impeded by the lack of household level data comparable over time: consumption measures in the 1999/00 round of the National Sample Survey (NSS) were contaminated by changes in the questionnaire design. ${ }^{3}$ The recent release of the 2004/05 round, which uses the same methodology as earlier NSS rounds (namely 1993/94, 1987/88 and 1983), provides an opportunity to re-examine how the benefits of growth are distributed across the entire income distribution.

This paper aims to document the extent to which Indian growth has benefited the bottom of the income distribution over the last two decades. Did the impressive growth performance translate into commensurate poverty reduction, or were most gains captured by the relatively well-off? How did growth and changes in inequality contribute to poverty reduction? Did the pattern of growth across the income distribution change as India's economic expansion accelerated? Was the inclusiveness of growth across Indian states influenced by certain factors or policies such as financial development, education or labor legislation?

In answering these questions, this paper builds on a rich body of literature that has examined various aspects of growth, poverty and inequality in India in earlier time periods. Most closely related, Ravallion and Datt (1996) and Datt and Ravallion (2002) study the relationship between

\footnotetext{
${ }^{2}$ According to the Post-Poll survey of the 2004 National Election Study, 43 percent of respondents believe that the economic policies of the National Democratic Alliance government (1999-2004) have benefited only the rich (http://www.csdsdelhi.org/nes2004/ques.htm).

${ }^{3}$ Nationally representative household surveys in India are conducted by the NSSO annually. However the Planning Commission's periodical estimates of poverty are based on the "quinquennial" or "thick" rounds of the NSS, which involve substantially larger samples.
} 
growth and poverty in the Indian context in the 1960-1993/94 period, ${ }^{4}$ and find that sectoral composition is an important factor determining growth. Ravallion and Datt (2002) and Besley, Burgess and Esteve-Volart (2007) exploit the heterogeneity within India at the state level to investigate whether Indian states' ability to achieve faster poverty alleviation or to better channel growth into reducing poverty is correlated with certain state characteristics, such as human and physical capital accumulation, regulation, farm productivity and others. Deaton and Dreze (2002) develop a methodology to adjust the 1999/00 household consumption measures and document the evolution of inequality between 1993/94 and 1999/00, pointing to a slight increase in inequality in urban Indian, across states and between rural and urban areas. Consistent evidence has been found by Banerjee and Piketty (2005) who use income tax records to document a sharp rise in income among the very highest income earners in the 1990s. And finally, considerable attention has been devoted to the growing divergence of incomes across Indian states (e.g., Ahluwalia, 2002, Aiyar, 2001, Bajpai and Sachs, 1996, Bhattacharya and Sakthivel, 2004, Purfield, 2006).

The remainder of the paper is organized as follows. Section II presents some evidence on the evolution of growth, poverty and inequality in India. Section III traces the growth pattern of household consumption across the income distribution in the last two decades. In Section IV, we exploit variation across states in India to ascertain which state characteristics (such as financial development, education or labor policies) influence the inclusiveness of growth. Section V concludes.

\section{Growth, Poverty, And Inequality in the Last Two Decades}

\section{A. Growth and Poverty}

India's economy has been expanding at a robust pace in the last two decades. The annual growth rate of real GDP per capita accelerated from 3 percent in 1983-1993/94 to an average of $4 \frac{1}{2}$ percent in the post reform period 1993/94-2004/05. ${ }^{56}$ A similar pattern is observed in private per capita consumption, as measured in national account statistics (NAS).

\footnotetext{
${ }^{4}$ Besley, Burgess, and Esteve-Volart (2007) and Purfield (2006) estimate the growth elasticity of poverty for a period spanning 1960-2000.

5 These particular periods were chosen based on availability of household survey data. NSS quinquennial rounds were conducted in 1983, 1987/88, 1993/94, 1999/00 and 2004/05. Due to the substantial differences in the measurement of per capita expenditure in the 1999/00 round, the analysis will not rely on data from this round.

${ }^{6}$ The acceleration of the growth rate in the Indian economy may have started in the early to mid 1980s as argued by Delong (2004) and Rodrik and Subramanian (2004) due to a pro-business attitudinal shift by the government.
} 


\begin{tabular}{|c|c|c|c|c|c|}
\hline \multicolumn{6}{|c|}{ Table 1. India: Economic Growth in the 1980s and 1990s } \\
\hline & \multicolumn{5}{|c|}{ Average Annual Growth of Per Capita 1/ } \\
\hline Period & GDP & $\begin{array}{c}\text { Private } \\
\text { Consumption } \\
\text { NAS }\end{array}$ & $\begin{array}{c}\text { Private } \\
\text { Consumption } \\
\text { NSS } 2 /\end{array}$ & $\begin{array}{c}\text { Private } \\
\text { Consumption } \\
\text { Rural } \\
\text { NSS 2/ }\end{array}$ & $\begin{array}{c}\text { Private } \\
\text { Consumption } \\
\text { Urban } \\
\text { NSS 2/ }\end{array}$ \\
\hline 1983-1993/94 & 3.11 & 1.84 & 0.91 & 0.76 & 1.23 \\
\hline 1993/94-2004/05 & 4.43 & 3.30 & 1.31 & 1.12 & 1.74 \\
\hline
\end{tabular}

Household survey data, on the other hand, point to a much slower improvement in the standard of living, as captured in monthly expenditures per capita. ${ }^{7}$ According to the NSS data, over the period 1983 to $1993 / 94$, the average annual growth rate of per capita expenditure was only half as large as the rate measured in the NAS. In the 1990s it shrunk to 40 percent of NAS growth rate. Similar disparities exist in the level of consumption measured, with the gap between the two measures growing over time. ${ }^{8}$ The Indian growth paradox of the 1990 s is subject to intense debate, with one side taking the view that the survey systematically underestimates the consumption of all respondents, with the implication that consumption is growing far faster than the survey data suggest (Bhalla, 2003). Another interpretation posits that a very large share of growth went to the very rich, who are much less likely to be picked up in expenditures surveys.' Using income tax data, Banerjee and Piketty (2005) find that growth of the top 1 percent of incomes can explain 20-40 percent of the gap between average consumption growth in surveybased and NAS data. The latter interpretation has serious implications for the ability of survey data to trace how the benefits of growth were distributed across the income distribution, and suggests that the top percentiles of the population are benefiting substantially more than survey evidence suggests. However, analyzing this data does provide a point of departure to answer a very important question on the current policy agenda in India.

\footnotetext{
${ }^{7}$ We use the official state-level deflators, i.e., Consumer Price Index for Agricultural Labor (CPIAL) for the rural sector and Consumer Price Index for Industrial Workers (CPIIW) for the urban sector, to convert nominal expenditures to base year (1993/94) values. Note however that there are serious concerns about the appropriateness of these deflators as described in Deaton (2003).

${ }^{8}$ Consumption reported in the NSS captured 62 percent and 41 percent of the private consumption reflected in the NAS in 1993/94 and 2004/05 respectively.

${ }^{9}$ As Ravallion (2001) notes, this view is corroborated by the existence of an income effect on underreporting and noncompliance in consumption and income surveys, which also squares with the fact that the divergence between NAS and NSS data has increased with economic growth. In addition, Sundaram and Tendulkar (2001) find that the NSS-NAS gap is most pronounced for commodities consumed more heavily by higher income groups.
} 
Over the last two decades, the incidence of poverty fell by nearly 20 percentage points. As of 2004/05, $253 / 4$ percent of people in urban areas and 28 percent of people in rural areas lived below the poverty line. ${ }^{10,11}$ Poverty depth decreased by more than 50 percent during this time period. Figure 1 shows that there was substantial heterogeneity in the progress toward poverty

\begin{tabular}{|lcccccc|}
\hline \multicolumn{7}{|c|}{ Table 2. India: Evolution of Poverty } \\
\hline \multicolumn{7}{|c|}{ Poverty Rate 1/ } \\
All India & Rural & Urban & All India & Rural & Urban \\
1983 & $45.2 \%$ & $46.2 \%$ & $42.1 \%$ & $12.6 \%$ & $13.0 \%$ & $11.5 \%$ \\
$1987 / 88$ & $39.3 \%$ & $39.3 \%$ & $39.2 \%$ & $9.6 \%$ & $9.4 \%$ & $10.4 \%$ \\
$1993 / 94$ & $35.8 \%$ & $36.8 \%$ & $32.8 \%$ & $8.4 \%$ & $8.4 \%$ & $8.3 \%$ \\
$2004 / 05$ & $27.5 \%$ & $28.0 \%$ & $25.8 \%$ & $5.7 \%$ & $5.5 \%$ & $6.2 \%$ \\
\hline Source: NSSO various rounds; and Fund staff estimates. & \\
1/ Defined as the share of the population below the poverty line. \\
2/ Defined as the poverty rate multiplied by the average value of the shortfall \\
from the poverty line. \\
3/ At 93/94 prices in rural India. \\
\hline
\end{tabular}
reduction among India's states. Even so, the poorest state in 1983, Orissa, remained the state with the highest poverty incidence, with more than 45 percent of population living below the poverty line in 2004/05. Similarly, Punjab, whose poverty rate was the lowest in India in 1983, remained in this position, with a poverty rate of just 8 percent in 2004/05.

\section{B. Inequality}

All measures point to a significant increase in overall inequality in the 1990 s, particularly in urban areas, and within all but one state (in Bihar inequality remained flat). While inequality was stable (in urban India) and declining (in rural India) in the 1980s, this trend was reversed in the 1990s. The change in the distribution of consumption across households can explain the lower than expected poverty reduction. Despite the pick-up in consumption growth from the 1980 s to the 1990s, the decline in poverty incidence remained roughly unchanged: the poverty rate fell by 9.4 percentage points (or 20.8 percent) in the 1983-1993/94 period and 8.4 percentage points (or 23.4 percent) during the slightly longer 1993/94-2004/05 period. With real consumption growth significantly higher in urban areas especially in the 1990s, in most states and in India as a whole the urban-rural gap widened.

\footnotetext{
${ }^{10}$ The poverty line is defined in India as the minimum subsistence income that can support the consumption of 2400 calories in rural areas and 2100 calories per person in urban areas. The poverty line was first established in 1979 and since then it has been periodically adjusted for inflation.

${ }^{11}$ An alternative measure of consumption, that uses different recall periods for durable and non-durable goods, places India's poverty rate at 21 percent in 2004/05 down from 26.1 percent in 1999/00. Unfortunately, comparable estimates for earlier years are not available under this alternative definition.
} 
Table 3. India: Evolution of Inequality

\begin{tabular}{|c|c|c|c|c|c|c|c|c|c|c|c|c|}
\hline \multirow[b]{3}{*}{$1982 / 83$} & \multicolumn{3}{|c|}{ Gini } & \multicolumn{3}{|c|}{ Theil Index } & \multicolumn{3}{|c|}{ Log (PCE $95 /$ PCE 5) 1/ } & \multicolumn{3}{|c|}{$\begin{array}{l}\text { Variance of Log } \\
\text { Consumption }\end{array}$} \\
\hline & All India & Rural & Urban & All India & Rural & Urban & All India & Rural & Urban & All India & Rural & Urban \\
\hline & 0.319 & 0.312 & 0.340 & 0.198 & 0.191 & 0.215 & 1.774 & 1.740 & 1.866 & 0.303 & 0.290 & 0.342 \\
\hline $1987 / 88$ & 0.313 & 0.301 & 0.349 & 0.200 & 0.186 & 0.241 & 1.688 & 1.621 & 1.887 & 0.279 & 0.258 & 0.348 \\
\hline 1993/94 & 0.303 & 0.285 & 0.343 & 0.191 & 0.171 & 0.235 & 1.638 & 1.537 & 1.878 & 0.263 & 0.234 & 0.345 \\
\hline 2004/05 & 0.325 & 0.298 & 0.378 & 0.228 & 0.196 & 0.288 & 1.692 & 1.541 & 2.029 & 0.285 & 0.240 & 0.402 \\
\hline
\end{tabular}

Source: NSSO various rounds and Fund staff estimates.

$1 / \log$ of the ratio of the per capita expenditure of the 95th percentile relative to the 5th percentile.

Keeping in mind all the caveats with the representativeness of survey data of the consumption of the rich and the growing disparity of the NAS and NSS data that may reflect precisely the growth of income at the upper end, these changes in inequality may very well provide a lower bound estimate of the true changes in income distribution.

Anecdotal evidence suggests that wealth inequality may be even higher. Ahya and Sheth (2007) estimate that India has witnessed an increase in wealth of over 100 percent of GDP in the past four years from three key sources: the equity market, the residential property market, and gold (see also Purfield, 2007). With 4-7 percent of the population participating in the stock market, 47 percent of the population owning a 'pucca' house, and the top 34 percent of households holding 71 percent of the value of consumer durables (including gold and jewelry), it is likely that the bulk of wealth accretion was concentrated within a very small segment of the population (Ahya and Sheth, 2007). Supportive of this conjecture is Jayadev et al. (2007)'s finding of a small but perceptible rise in the level of interpersonal wealth inequality in the 1990s based on household NSS surveys on debt and investment (though these surveys suffer from similar, if not even larger, problems of representativeness of the wealthy as the consumption surveys).

\section{Decomposing Poverty Reduction}

How much more or less poverty reduction might have been achieved had growth occurred without changes in the income distribution? To examine this, changes in poverty can be decomposed into the change attributable to "pure growth" (holding inequality constant) and the change attributable to the distributional component (holding the mean of consumption constant). ${ }^{12}$ To do so, we express the poverty rate at time $t$ as a function of the level of consumption, $\mathrm{m}_{\mathrm{t}}$, and the distribution of income or the Lorenz curve, $1_{t}$, i.e. $\mathrm{P}_{\mathrm{t}}=\mathrm{P}\left(\mathrm{m}_{\mathrm{t}}, \mathrm{l}_{\mathrm{t}}\right)$. We adopt the methodology proposed by Dhongde (2007), which provides a path-independent and complete decomposition, by taking the average of the two growth components (with distribution

\footnotetext{
${ }^{12}$ For a similar decomposition for earlier time periods, see Jain and Tendulkar (1990), Datt and Ravallion (1992), Deaton and Dreze (2002), Bhanumurty and Mitra (2004) and Dhongde (2007).
} 
kept fixed as in time $\mathrm{t}=0$ and $\mathrm{t}=1$ ), and the average of the two distribution components (with average consumption held fixed at $\mathrm{t}=0$ and $\mathrm{t}=1$ ), namely:

$$
\mathrm{P}_{11}-\mathrm{P}_{00}=\frac{\left(\mathrm{P}_{10}-\mathrm{P}_{00}\right)+\left(\mathrm{P}_{11}-\mathrm{P}_{01}\right)}{2}+\frac{\left(\mathrm{P}_{10}-\mathrm{P}_{11}\right)+\left(\mathrm{P}_{00}-\mathrm{P}_{01}\right)}{2}
$$

where $\mathrm{P}_{00}=\mathrm{P}\left(\mathrm{m}_{0}, \mathrm{l}_{0}\right)$ and $\mathrm{P}_{11}=\mathrm{P}\left(\mathrm{m}_{1}, \mathrm{l}_{1}\right)$. This simple decomposition abstracts from the fact that changes in the distribution of income may affect (and be affected by) the average growth rate (i.e., the observed growth rate may not have been the same had the distribution of income not changed). ${ }^{13}$

The counterfactual simulation, suggests that in the 1980s, changes in the distribution of income enhanced the effect of growth on poverty reduction (Table 4). ${ }^{14}$ In rural India, poverty reduction from "growth alone" would have been 27 percent lower had the distribution of income not changed in favor of the poor. In urban India, "growth alone" accounts for the entire poverty decline.

In the period from 1993 to 2004/05, on the other hand, changes in the distribution of consumption moderated the extent to which growth reduced poverty. Distribution-neutral growth would have generated a poverty decline in rural India that was 22 percent higher; in urban areas, the decline in poverty would have been 76 percent higher. This finding suggests a marked change in the

\begin{tabular}{|c|c|c|c|c|}
\hline \multicolumn{5}{|c|}{ Table 4. India: Decomposing Changes in Poverty } \\
\hline & $\begin{array}{c}\text { Initial Level of } \\
\text { Poverty }\end{array}$ & $\begin{array}{c}\text { Change in } \\
\text { Poverty }\end{array}$ & $\begin{array}{c}\text { Contribution of } \\
\text { Growth }\end{array}$ & $\begin{array}{l}\text { Contribution of } \\
\text { Change in } \\
\text { Distribution }\end{array}$ \\
\hline \multicolumn{5}{|c|}{ 1983-1993/94 } \\
\hline Rural & 0.4617 & -0.0933 & -0.0683 & -0.0249 \\
\hline Urban & 0.4208 & -0.0925 & -0.0973 & 0.0047 \\
\hline All India & 0.4524 & -0.0940 & -0.0808 & -0.0132 \\
\hline \multicolumn{5}{|c|}{ 1993/94-2004/05 } \\
\hline Rural & 0.3684 & -0.0880 & -0.1071 & 0.0191 \\
\hline Urban & 0.3283 & -0.0702 & -0.1237 & 0.0536 \\
\hline All India & 0.3585 & -0.0837 & -0.1151 & 0.0314 \\
\hline
\end{tabular}
way the gains from growth were distributed across India's households in the relatively new market-oriented framework governing India's economic life.

\footnotetext{
${ }^{13}$ Cross-country evidence on the relationship between inequality and growth is mixed. Most recently, Banerjee, and Duflo (2003) establish that changes in inequality (in any direction) are associated with lower future growth rates, though they emphasize that this correlation does not warrant a causal interpretation.

${ }^{14}$ For this exercise, the average consumption growth in rural, urban and all India was applied for the particular period (as opposed to state-specific growth rates).
} 
Figure 1. Poverty and Inequality Across Indian States
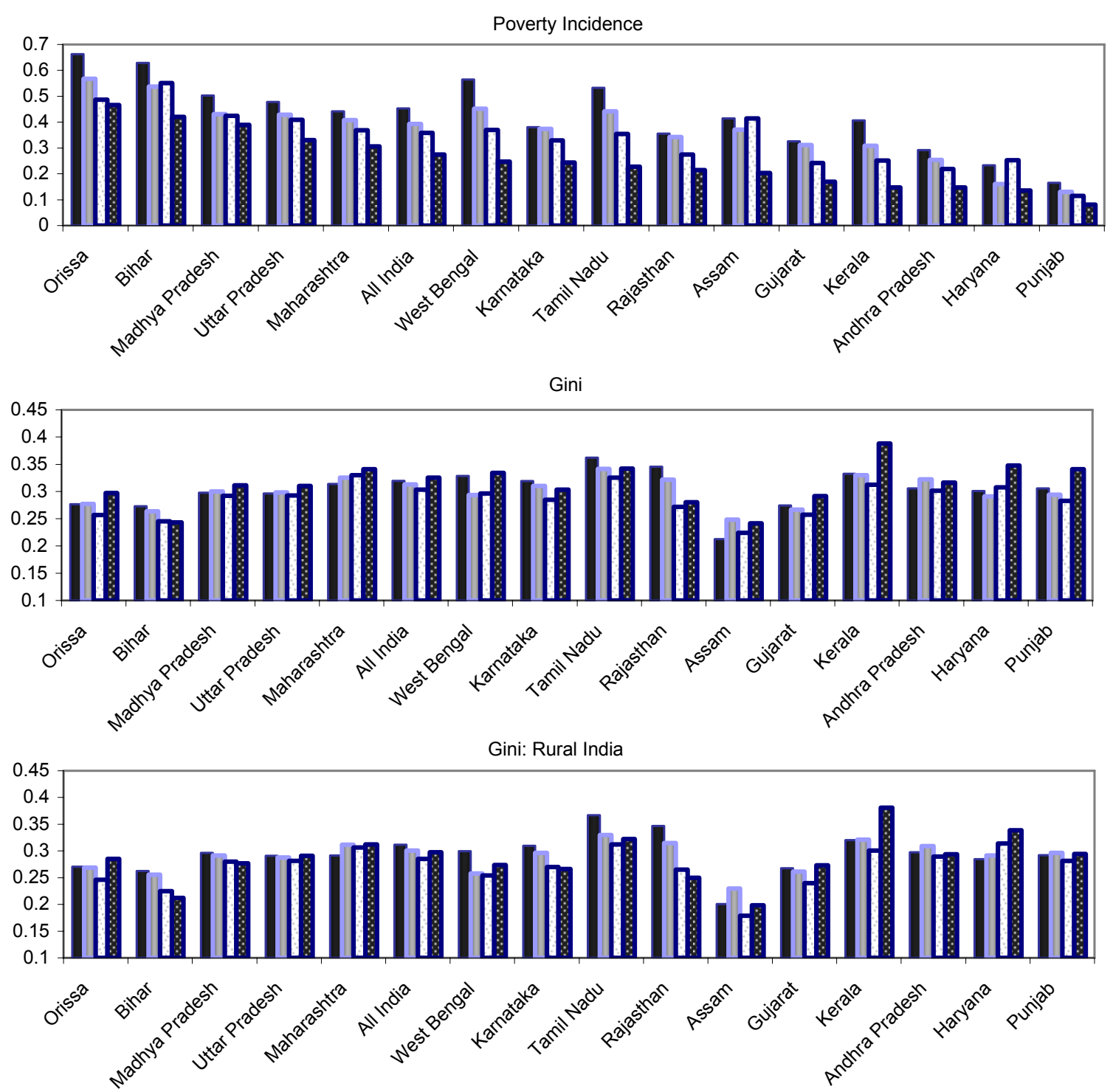

Gini: Urban India

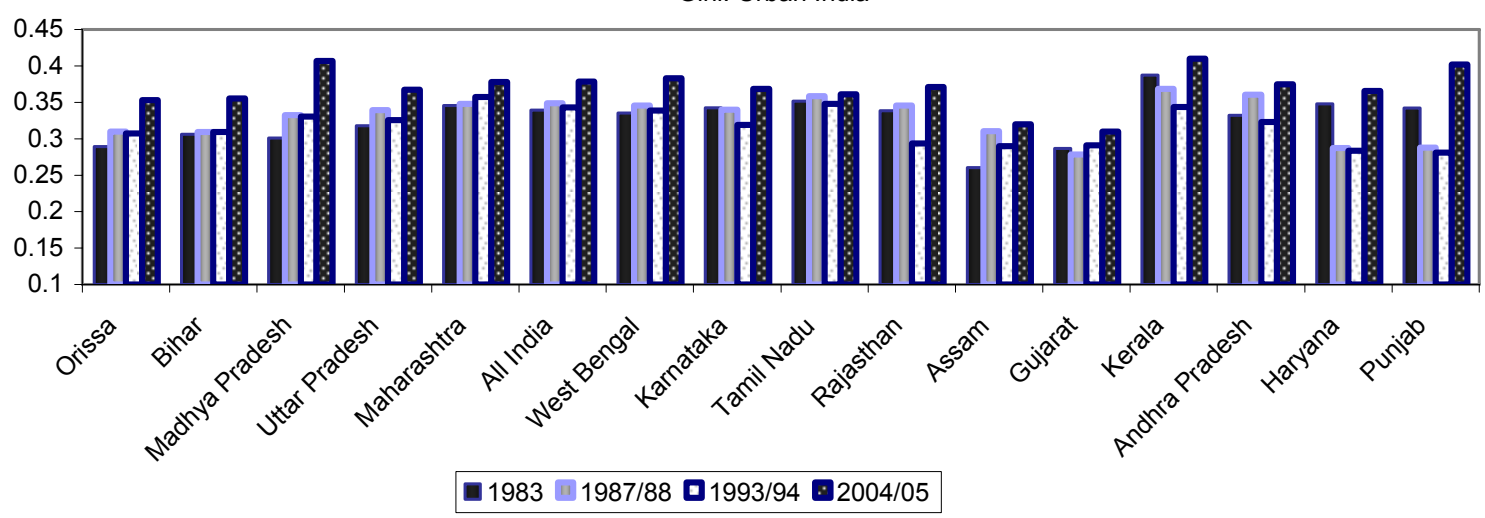

Source: NSSO various rounds and Fund staff estimates. 


\section{INCLUSIVENESS OF GROWTH}

\section{A. Patterns of Growth}

To gain a fuller picture of how the absolute gains from growth accrue across the income distribution, we calculate "growth incidence curves" of real monthly consumption per capita (Ravallion and Chen, 2003). The growth incidence curve depicts how the growth rate for a given quantile varies across quantiles ranked by expenditure, thus succinctly describing how inclusive growth was. A growth incidence curve increasing over all quantiles implies rising inequality, while a downward-sloping curve characterizes growth that was biased towards the poor.

Figure 2 presents the growth incidence curves for India, during the 1983-1993/94 and 1993/94-2004/05 period ${ }^{15}$. The top panel uses data for all India, the middle for urban India, and the bottom for rural areas. The annualized growth rate in the mean (horizontal solid line) and median (horizontal dashed line) incomes are also included as benchmarks.

The shift in the growth patterns of consumption across the income distribution is striking. From 1983 to 1993/94, growth in consumption at the bottom of the income distribution outpaced growth at the top, especially in rural India (Figure 2). In urban areas, growth was remarkably distribution-neutral. This pattern of growth is consistent with the explicit goal of the socialistinspired development policy of India until 1991 "to limit the economic power of the elite" (Banerjee and Piketty, 2005). As India launched market-oriented reforms in 1991 and overall growth accelerated, the shape of the growth incidence curve reversed, with far faster growth at the top than the bottom. Similar to the previous period, there was substantial difference between the experience of urban and rural areas, with stronger pro-rich bias of growth in urban areas. In almost all states growth became less equalizing in the 1990s as depicted in Figure 3, which plots the annualized growth rate of the bottom 30 percent of the population and the top 30 percent of the population.

Between 1993/94-2004/05, consumption of the richest grew by an average of 3 percent every year, while for the poorest, the growth rate was slightly above 1 percent. These estimates are likely too low. According to the NSS, over an 11 year period, consumption of the richest grew by 40 percent. Using income tax data (for a slightly different period, 1987/88-1999/00), Banerjee and Piketty (2005) find that the incomes of the top 1 percent increased 70 percent, while the incomes of the top 0.01 percent tripled.

\footnotetext{
${ }^{15}$ These calculations use the disaggregate household survey data from 1983, 1993/94, and 2004/05, with household expenditures adjusted to be comparable across states, and rural and urban areas and deflated to 1993/94 values using the official deflators of the Planning Commission.
} 
Figure 2. India: Patterns of Real Consumption Growth
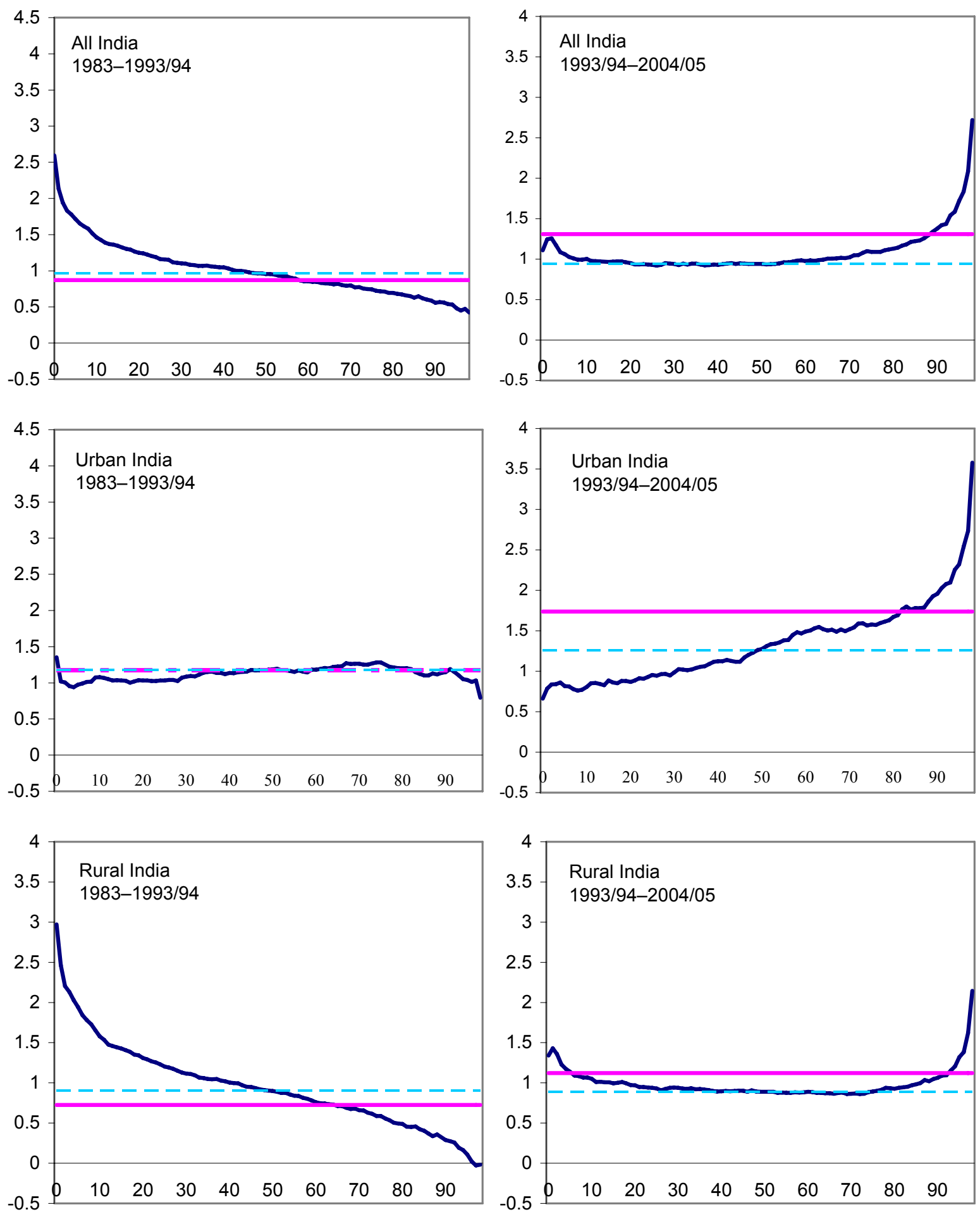

Source: NSSO various rounds and Fund staff estimates. 
Figure 3. Real Consumption Growth of the Top and Bottom 30 Percentile of the Population across India's States
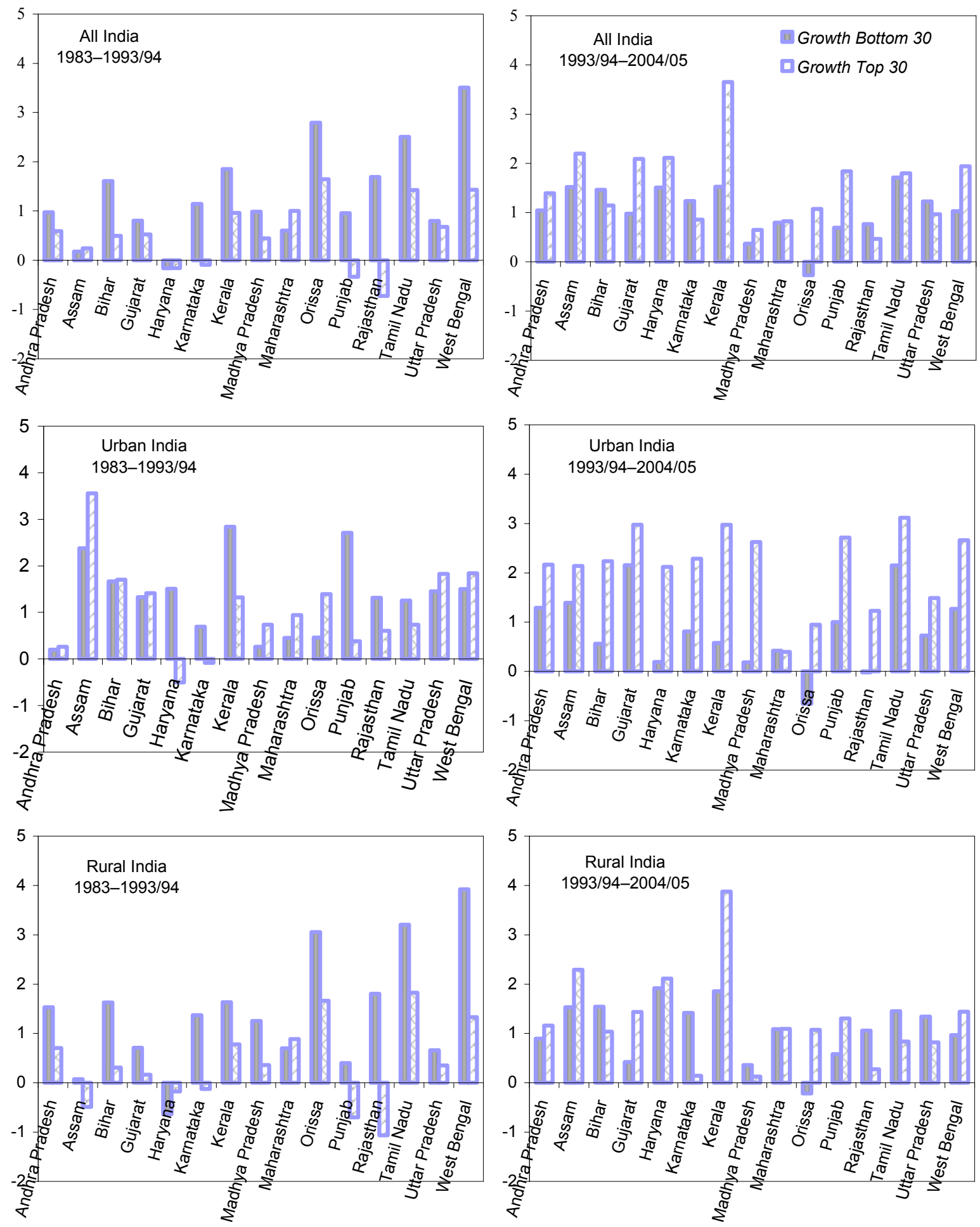

Source: NSSO various rounds; and Fund staff estimates. 
At the same time, our results suggest that consumption of the poorest increased by mere 8 percent. ${ }^{16}$ Given the substantial difference in initial level of consumption between the top and the bottom, the implications for absolute inequality are even larger. In fact, though aggregate growth was significantly higher in the 1990s (even when measured in NSS data), the bottom 50 percent of India's population experienced faster consumption growth in the previous decade.

The evolution of real wages paints a similar picture. We construct daily real wages from the Employment and Unemployment Schedules (Schedule 10) of the NSS for 15-65 year old adults engaged in regular salaried or casual wage labor, pooling the rural and urban sample. ${ }^{17}$ Using only observations with non-zero wage values, we construct the growth incidence curves of real daily wages for the 1980s and 1990s (Figure 4). Just as per capita consumption growth, real wage growth was a lot more pronounced at the top than at the bottom in the 1993/94-2004/05 period. Between 1983 and 1993/94, real wage growth at the bottom generally outpaced the growth of wages at the top. Note, however, that analyzing wages in this manner overlooks possibly important changes in labor participation, unemployment etc. which influence the sample of observed wages and complicate the interpretation of the growth incidence curves. Thus, for the rest of the study, we focus the analysis on growth rates in per capita consumption rather than wages.

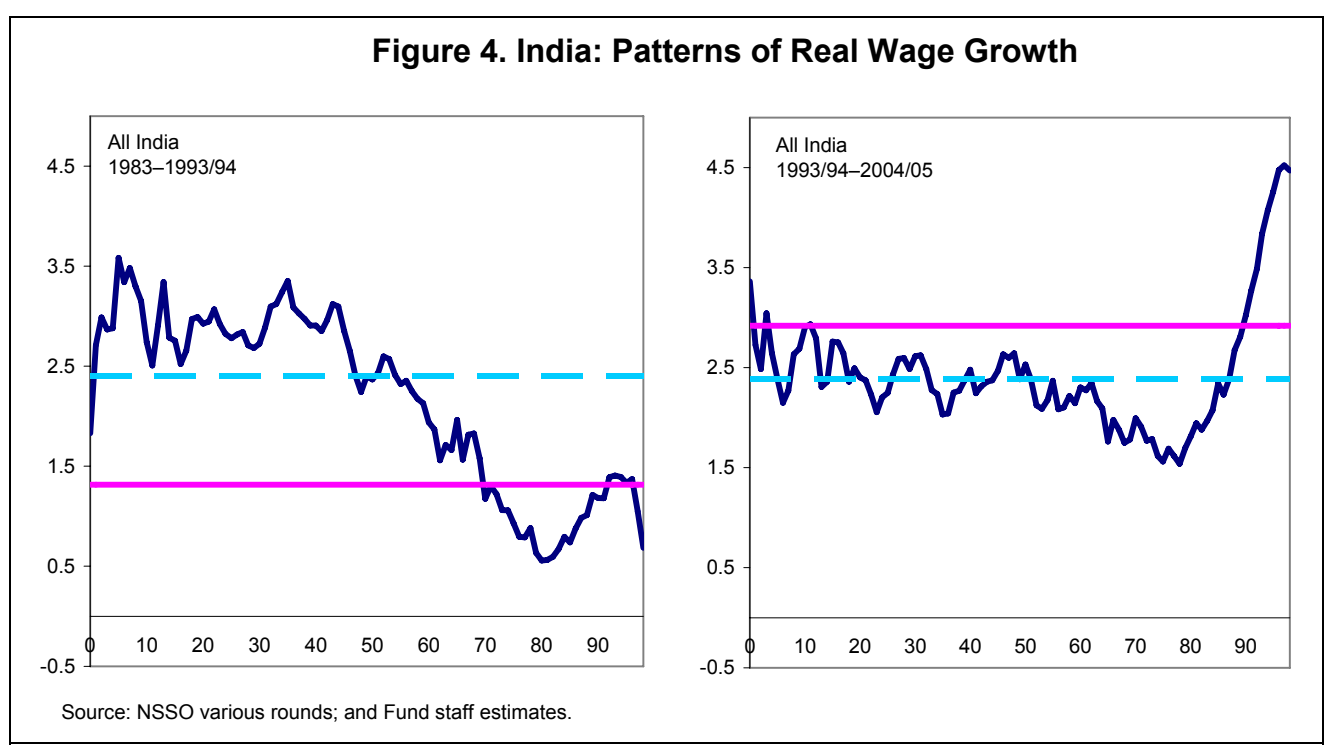

\footnotetext{
16 This pattern of consumption growth in the 1990s is consistent with the responses in the Post-Poll survey of the 2004 National Election Study. While more than 40 percent of the upper middle class respondents agreed that things improved during the National Democratic Alliance regime (1999-2004), only 20 percent to the poor felt that way (The Hindu, May 20, 2004).

${ }^{17}$ Note that in the 1993/94 round, 0.9 percent of nonmissing wage observations were for daily wages of less than 0.5 rupee. Such low values of real wages were not observed in any of the two earlier rounds (in 1983 and 1987/88), thus these observations were dropped.
} 
Simple cuts of the household samples across several characteristics of the household head reveal interesting changes in how consumption growth varied along these dimensions (Figure 5). First, we split households according to the educational achievement of the household head (Panel A). Then, we consider the principal industrial occupation of the head of the household (Panel B), and finally we split households into those that belong to the historically disadvantaged scheduled castes (SC) or scheduled tribes (ST) versus the rest of the population (Panel C). We then calculate the unconditional overall growth of average per capita consumption for each of these groups for the 1980s and 1990s. The growth rates estimated from these unconditional means should not be interpreted as measuring the returns to education, occupation etc. in India, but rather as a simple description of the evolution of consumption across households in India.

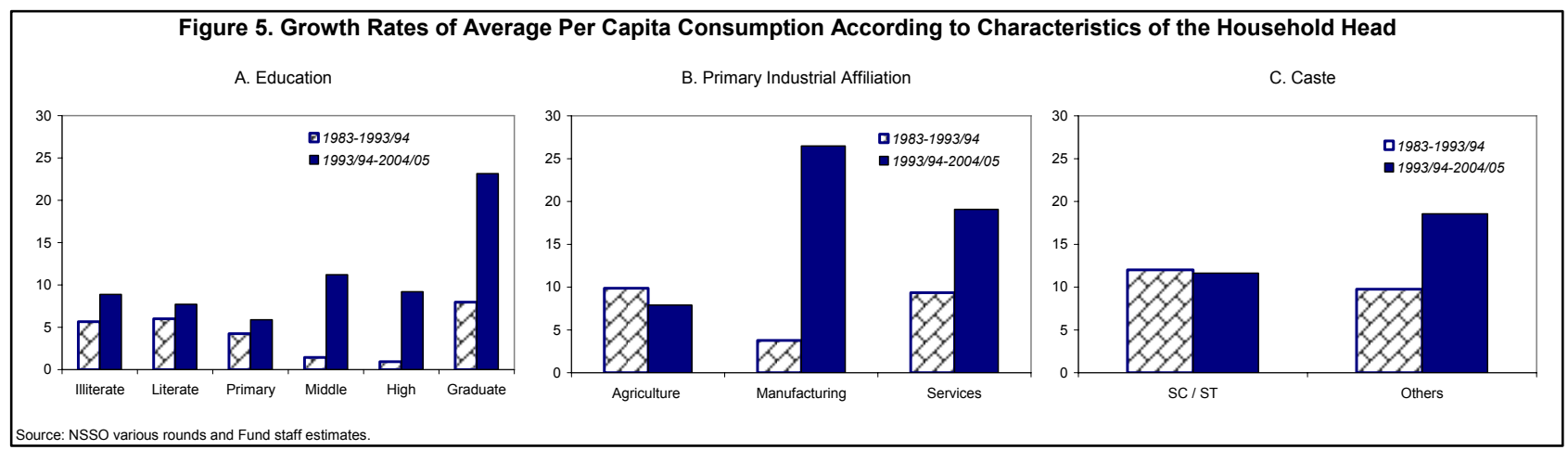

During the 1980s, consumption growth was relatively balanced across households with different characteristics. In fact, with the exception of college graduates, growth rates of consumption were declining with the education of the household head (and with the initial level of consumption), thus tightening the distribution of income. In the 1990s, the unconditional means suggest that the consumption of households with completed middle school and above rose substantially more than the consumption of those with lower education; the fastest growth in consumption was registered by those with college education and above. Similarly, households involved in the manufacturing and services sectors experienced a much larger increase in consumption in the 1990s relative to those whose primary source of income came from agriculture. Growth in consumption for these sectors was also substantially faster relative to the 1980s. The growth in consumption, which is remarkably similar across SC/ST households and other castes in the 1980s, also seems to be diverging in the 1980 s with non-SC and ST experiencing faster consumption growth.

\section{B. Quantifying Growth Inclusiveness}

While growth incidence curves describe distributional changes well, a simple summary statistic is useful for making comparisons over time and across states, and for statistical analysis. How might the inclusiveness of growth be defined? The definition of the deputy chairman of the Planning Commission, "a growth process in which people in different walks in life... feel that 
they too benefit significantly from the process," 18 suggests using a measure that captures the unevenness in consumption growth rates across households. We therefore define inclusiveness, or "pro-poor bias of growth" as the difference between the consumption growth rate of the poorest and richest 30 percent of the population. ${ }^{19,20}$

We use variation across India's states and over time to establish whether there is relationship between the inclusiveness of growth, the growth rate and its sectoral composition. ${ }^{21}$ Specifically, we compute for each of the 15 large states in India and for each of the following periods, 1983-1987/88, 1987/88-1993/94 and 1993/94-2004/05, the inclusiveness of growth as defined above, the average annual growth rate of real state GDP per capita, as well as the per capita growth rates of the agricultural, industrial and service sector. We then regress the inclusiveness of growth on per capita growth rates. We include period fixed-effects to control for economy-wide changes, and state fixed-effects to control for time-invariant heterogeneity across states. The coefficients on the overall and sectoral growth rates are presented in Table 5.

\begin{tabular}{|c|c|c|c|c|c|c|c|c|}
\hline & \multicolumn{2}{|c|}{ Bottom10-Top10 } & \multicolumn{2}{|c|}{ Bottom20-Top20 } & \multicolumn{2}{|c|}{ Bottom30-Top30 } & \multicolumn{2}{|c|}{ Bottom50-Top50 } \\
\hline & $(1)$ & $(2)$ & $(3)$ & $(4)$ & $(5)$ & $(6)$ & $(7)$ & $(8)$ \\
\hline Real Per capita NSDP growth & $\begin{array}{l}-0.016 \\
{[0.202]}\end{array}$ & & $\begin{array}{c}0.005 \\
{[0.159]}\end{array}$ & & $\begin{array}{c}0.001 \\
{[0.134]}\end{array}$ & & $\begin{array}{c}0.001 \\
{[0.095]}\end{array}$ & \\
\hline Real Per capita Agriculture growth & & $\begin{array}{c}0.029 \\
{[0.072]}\end{array}$ & & $\begin{array}{c}0.032 \\
{[0.051]}\end{array}$ & & $\begin{array}{c}0.021 \\
{[0.040]}\end{array}$ & & $\begin{array}{c}0.013 \\
{[0.026]}\end{array}$ \\
\hline Real Per capita Industry growth & & $\begin{array}{c}0.139 \\
{[0.109]}\end{array}$ & & $\begin{array}{c}0.145 \\
{[0.087]}\end{array}$ & & $\begin{array}{l}0.142^{*} \\
{[0.071]}\end{array}$ & & $\begin{array}{l}0.105^{\star *} \\
{[0.049]}\end{array}$ \\
\hline Real Per capita Services growth & & $\begin{array}{c}-0.591^{* * *} \\
{[0.182]}\end{array}$ & & $\begin{array}{c}-0.496^{\star * *} \\
{[0.143]}\end{array}$ & & $\begin{array}{c}-0.421^{* * *} \\
{[0.121]}\end{array}$ & & $\begin{array}{c}-0.292^{\star * *} \\
{[0.083]}\end{array}$ \\
\hline Number of Observations & 45 & 45 & 45 & 45 & 45 & 45 & 45 & 45 \\
\hline
\end{tabular}

We first note that there is no evidence of correlation between the speed of growth and its inclusiveness. Though the coefficients on real state domestic product growth are imprecisely

\footnotetext{
${ }^{18}$ Ahluwalia, Montek, Business Standard June 29, 2007.

${ }^{19}$ Given the nature of the policy debate in India, this seems to be a more appropriate definition than for example the standard deviation of growth rates, or other measures that describe the unevenness of growth.

${ }^{20}$ The choice of 30 percent is arbitrary, and as a robustness check, we analyze the difference in the growth rates between the bottom and top 10 percent, 20 percent, and below and above the median.

${ }^{21}$ The importance of the sectoral composition of growth in India is documented in Ravallion and Datt (1996), who find that growth in agriculture led to substantially more poverty reduction than growth in manufacturing in India between 1960 and 1993 .
} 
estimated, their magnitude is very close to zero. Second, faster growth in services is associated with a larger gap between the consumption growth of the poor and the rich, in favor of the rich. The service sector includes a mix of activities that may be of varying importance to the bottom as well as the top of the income distribution. A finer disaggregation of the services sector reveals that, just as expected, the observed negative correlation is driven by the expansion of the banking and insurance sector within the services sector, which benefits predominantly highly educated people. Thus, while service growth is associated with absolute gains by the poor, the results indicate that it is associated with even more benefits to the people at the top.

For broader definitions of inclusiveness of growth, such as the difference in growth below and above the median, higher growth of the secondary/industrial sector is correlated with a larger pro-poor bias of consumption growth, presumably because of the lower threshold of skills and education for employment in manufacturing and construction.

This set of correlations provides some suggestive evidence why the inclusiveness of growth was different in the 1990s, relative to the previous decade. Growth rates in the service sector accelerated in the 1990s, and the service sector increased

Table 6. Sectoral Composition of Growth

\begin{tabular}{|lccccc|}
\hline \multicolumn{7}{c}{ Table 6. Sectoral Composition of Growth } \\
\hline & \multicolumn{2}{c|}{ Average Growth Rate } & \multicolumn{3}{c|}{ Share of GDP } \\
Real GDP & 5.22 & 6.23 & & & \\
Agriculture & 3.56 & 2.71 & 0.37 & 0.30 & 0.20 \\
Industry & 5.60 & 6.59 & 0.24 & 0.25 & 0.26 \\
Services & 6.42 & 7.97 & 0.39 & 0.45 & 0.54 \\
\hline Source: RBI, National account statistics; and Fund staff estimates. \\
\hline
\end{tabular}
substantially its share in overall GDP (from 40 percent in 1983/84 to 54 percent in 2004/05). Most importantly, within the services sector, banking, insurance and communications registering the greatest relative expansion. It is precisely these sectors that are more important to the top of the income distribution than the bottom. Unfortunately, as is typically the case with macro analysis, without exogenous variation it is difficult to rule out alternative explanations: for example, the causality could run in the other direction. The growth in the banking and insurance sectors could reflect increase demand from the increasingly wealthy populations in those states.

\section{The Role of Policy for InClusiveness of Growth}

Why has economic growth been less inclusive in some states than others? Do economic policies affect how the benefits of growth are distributed across households? A large literature has analyzed the heterogeneity of the Indian experience to examine why and how certain Indian states have experienced faster growth and poverty reduction than others (for a survey, see Besley, Burgess, and Esteve-Volart, 2007). Few have explored what affects the distribution of growth across households. Building on the previous work, we consider whether factors that have been shown to be associated with the growth and poverty reduction experiences of India's states are also related to the distributional impact of growth. More importantly, these are all policies that have been highlighted as crucial for making growth faster and more inclusive in the Approach Towards the $11^{\text {th }}$ Plan Paper of the Planning Commission of India. Thus, the purpose 
of this exercise is to establish whether historically there was a link between these policies and growth's inclusiveness, rather than identify and rank all potential factors that may influence the pattern of consumption growth across households.

Numerous studies have argued that labor regulations are an important determinant of the investment climate in India. The Industrial Disputes Act, which governs hiring and firing of labor in manufacturing was initially passed at the central level, but state governments were given authority to amend it. Besley and Burgess (2004) classify these amendments as proworker, proemployer or neutral and demonstrate that labor regulations significantly affect manufacturing performance across Indian states. ${ }^{22}$ In particular, additional labor protection led to lower growth in manufacturing. A similar conclusion is reached by Ahsan and Pages (2007), who find that laws that increase job security or increase the cost of labor disputes substantially reduce registered sector employment, without increasing the labor share. Hasan, et al (2007) find that lower labor protection is associated with higher elasticity of labor demand.

What role might state labor regulations have in determining who gains from growth? We have already seen that the sectoral composition of the economy matters for the distribution of growth across incomes. In Table 7, we measure whether labor regulations

\begin{tabular}{|lcc|}
\hline \multicolumn{3}{|c|}{ Table 7. Labor Regulation and State GDP Structure } \\
\hline & $\begin{array}{c}\text { Log (Service GSDP / } \\
\text { Industry GSDP) }\end{array}$ & $\begin{array}{c}\text { Log (Service GSDP / } \\
\text { Mfg GSDP) }\end{array}$ \\
\cline { 2 - 3 } & $0.077^{*}$ & $0.079^{* *}$ \\
Labor Regulation (Lagged) & {$[0.044]$} & {$[0.034]$} \\
$N$ & 330 & 330 \\
\hline \multirow{2}{*}{$\begin{array}{l}\text { Note: All regressions include state and year fixed effects. Robust standard } \\
\text { errors, clustered at the state level in parentheses. The data are for 15 major } \\
\text { states for the period 1983-2004. }\end{array}$} \\
\hline
\end{tabular}
affect the sectoral composition of the states' economies. Using annual sectoral GDP data for states from1980-2004 period, we regress the ratio of services output to manufacturing output on labor legislation, and state and year fixed effects. ${ }^{23}$ The service sector expands more quickly than the industrial sector in states that amended labor regulations in favor of workers. This is logical, as the Industrial Disputes act applies to manufacturing workers, but not to service workers. Given the above results that sectoral composition is related to the inclusiveness of growth, it may be that regulations which sought to improve worker protections in fact ended up benefiting the rich more than the poor, by slowing down the expansion of the secondary sector.

A second factor that may play an important role is access to finance. Credit may enable people to move out of agriculture into higher-earning activities, such as organized manufacturing or

\footnotetext{
${ }^{22}$ For a critical review of this literature, see Bhattacharjea (2006).

${ }^{23}$ Malik (2003) and Purfield (2006) extend the Besley and Burgess (2004) dataset that classifies amendments of state labor laws. State-level amendments to the 1947 Industrial Dispute Act are coded so that pro-worker amendments receive a score of one, pro-employer amendments score negative one and neutral amendments receive a score of zero.
} 
certain types of self-employment. In India, Burgess and Pande (2005) find that the rural bank branch expansion program of 1977-1990 significantly lowered rural poverty and increased nonagricultural output. While financial development may boost growth, its effect on the distribution of growth across households is less clear.

A third factor considered is secondary education. In the approach to the $11^{\text {th }}$ Plan, the Planning Commission envisions a stronger focus on secondary, higher and technical education to promote faster and more inclusiveness growth. ${ }^{24}$ Evidence of the importance of human capital for economic growth across the world abounds. In the Indian context, Trivedi (2002) finds that for the period 1965-1992, secondary school enrollment rates are positively and significantly related to economic growth across Indian states. A larger supply of educated workers would also imply a greater increase in employment and smaller increase in the skilled wage premium as demand for skilled labor rises, thus a more even growth.

Access to infrastructure is also viewed as one of the key constraints to growth. Kochhar, et al (2006) show that states with higher quality infrastructure enjoy higher GDP growth and faster growth in industrial sectors. However, they do not consider whether infrastructure affects the distribution of income.

Finally we verify whether states' revenue expenditures on social services are associated with more inclusive growth. Social services include health, education, water supply, housing, urban development, nutrition and various welfare schemes for economically disadvantaged groups. As the majority of these services are targeted to poorer households, one might expect the inclusiveness of growth to be positively correlated with states' social spending.

\section{A. Empirical Strategy}

We adopt a panel regression framework, using measures of the inclusiveness of growth across several time periods for each state, to investigate whether the above variables are correlated with the distributional patterns of growth. By exploiting the variation both across states and over time, we can control for any time invariant state characteristic, such as preferences for equality, natural resource endowment etc. that may be somehow correlated with both policies and patterns of growth and thus obfuscate cross sectional studies. This is in contrast to previous studies that have focused on explaining the relationship between policies and growth elasticity of poverty reduction across states in a single cross-section (Besley, Burgess, and Esteve-Volart, 2007) or looked at the correlation of this elasticity with initial state characteristics (Ravallion and Datt, 2002). We thus estimate:

$$
y_{t, t-1, s}=\alpha+\beta X_{t-1, s}+\gamma Z_{t-1, s}+\tau_{t}+S_{s}+\varepsilon_{t, s}
$$

\footnotetext{
${ }^{24}$ For an analytical discussion of the approach to the role of education in the $11^{\text {th }}$ Plan, see Tilak (2007).
} 
where $y_{t, t-1, s}$ is a measure of the inclusiveness, or pro-poor bias, of growth in state $s$ between year $t$ and $t-1$ (The three periods considered are 1983-1987/88, 1987/88-1993/94 and 1993/94-2004/05 periods).

Inclusiveness is measured as the difference between the consumption growth rate of the bottom 30 and the top 30 percent of the population (as before, different cutoffs are also considered). $X_{t-}$ ${ }_{1, S}$ is a vector of state-level policy variables. We use the value at the beginning of the time period. These variables include: financial development (measured as the log of total real credit per capita and share of agricultural laborers who have a bank loan), labor regulation, availability of human capital (measured as the share of state population with secondary education and above), infrastructure (the main factor from a principal component analysis of installed electricity capacity per capita, kilometers of surfaced roads per state area, and share of households with access to drinking water), and states' spending on social services (measured as the log of state socioeconomic expenditure per capita). Since many of these variables could potentially be correlated with the overall level of development within a state, we control for the $\log$ of income per capita (measured as the real net state domestic product per capita) in the initial period and the number of people involved in agriculture as a share of the total workforce. These initial characteristics are included in the vector $Z_{t-1, s}$. Finally, $\tau_{\mathrm{t}}$ and $\mathrm{S}_{\mathrm{s}}$ represent period and state fixed effects. The necessary data are available for 15 major states in India (comprising 95 percent of India's population in 2004).

\section{B. Results}

Table 8 presents the results. Each of the policy variables is included separately in columns (1)-(7), while in columns (8)-(11) all the variables are included together in the regression. All specifications control for the real income per capita and industrial structure in the state in the beginning of the period. Columns (1)-(8) use as a measure of inclusiveness the difference between the consumption growth rate in the bottom 30 percent and top 30 percent. Columns (9)-(11) consider alternative measures; column (9) uses the difference between the bottom 10 percent and top 10 percent, column (10) the difference between the bottom 20 percent and top 20 percent, and column (11) the difference between those below and above the median. 


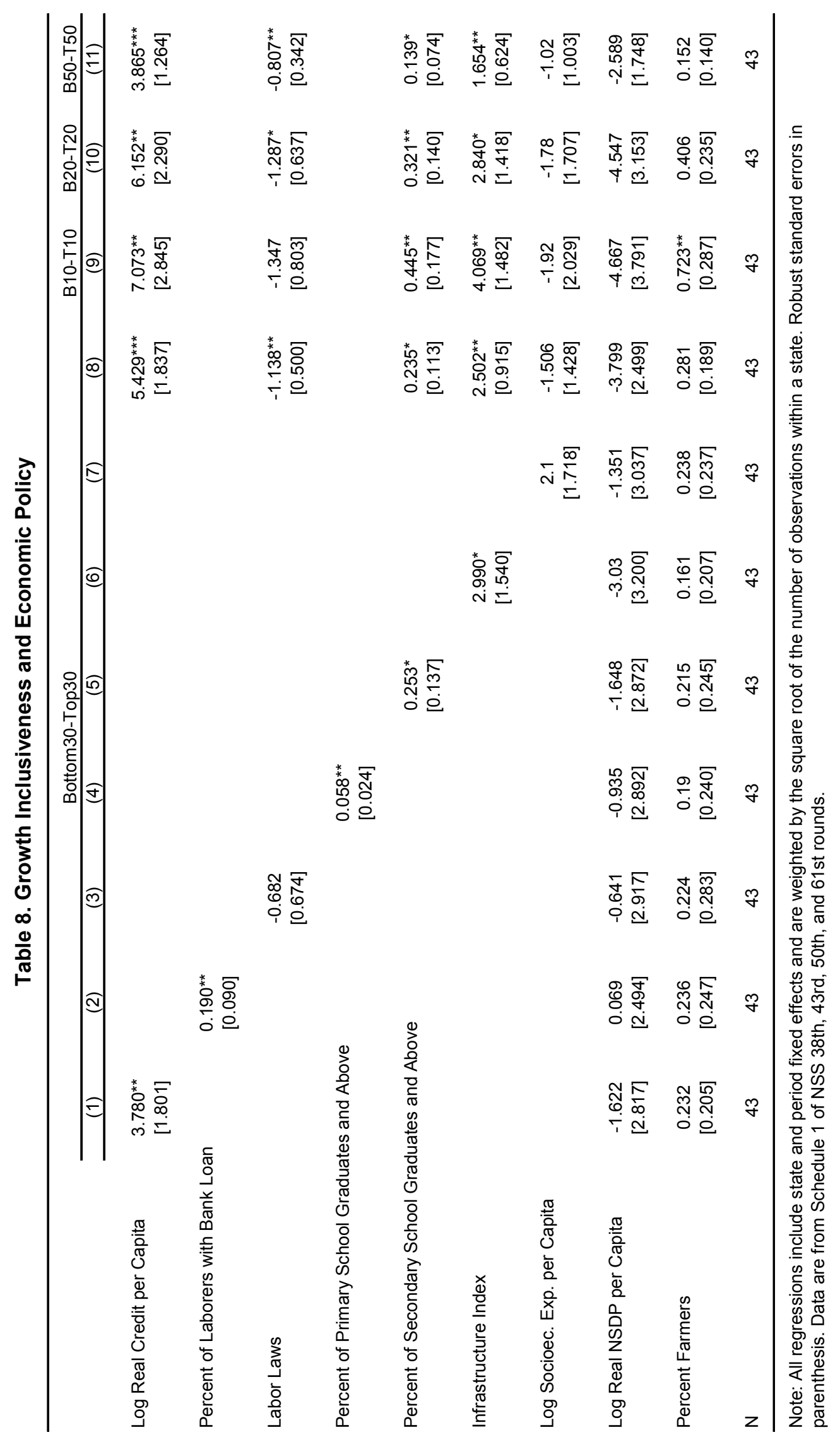


Several interesting relationships emerge from the data. First, higher financial development is significantly associated with more pro-poor growth (column 1). Within a state, as real credit per capita increases, the difference between consumption growth of the poor and the rich shifts in favor of the poor in relative terms. This correlation is consistent with the idea that better access to credit enables people in the bottom of the income distribution to move out of agriculture into higher-earning activities, such as organized manufacturing or certain types of self-employment. Since credit per capita is a very aggregate measure, which may not necessarily reflect access to financial services, as a robustness check we use household indebtedness information collected for agricultural laborers in the NSS Employment and Unemployment Schedule. For each state, we calculate the percentage of agricultural laborers with a loan from a bank, cooperative society or government (other major sources of loans are money lenders, relatives/friends, employers, shopkeepers). This measure, which obviously captures both the demand and supply of credit, should presumably be correlated with the access to formal credit by one of the poorest sections of the population. This alternative measure of financial development yields a similar result as the real credit per capita (column 2). A larger initial share of agricultural laborers with loans from formal financial institutions is associated with a more pro-poor pattern of subsequent growth. The results echo Besley, Burgess, and Esteve-Volart (2007) findings that across states, greater access to finance is correlated with higher growth elasticity of poverty.

There is some evidence that labor regulations, intended to protect workers from exploitation by factory owners, in fact reduced the relative gains of the poor. While the point estimate is not statistically significant in column (3), once other policy measures are controlled for, the absolute value of the coefficient increases and it is consistently statistically significant. As states amend their regulations towards greater flexibility for the employer, the poor seem to benefit more in terms of consumption growth. This finding is consistent with the pattern of economic development that labor regulations seem to bring to Indian states (Table 7) and the relative importance of services vs. manufacturing growth for the inclusiveness of growth (Table 6).

As a larger share of the population completes primary and especially secondary education and above, growth becomes relatively more pro-poor (columns 4 and 5). The correlation may stem from the fact that a larger supply of skilled labor eases the pressure on wages at the top of the income distribution. There is also evidence that better infrastructure is associated with more inclusive growth. Both the condition and unconditional correlations are strongly positive.

There does not appear to be a statistically significant correlation between state expenditures for socioeconomic purposes (such as health, education, etc.) and the distribution of growth rates across households. The lack of correlation may be due to potential reverse causality: social spending may be particularly high in states where growth is uneven. However, it may also reflect various gaps in the administration of antipoverty and other programs, such as poor targeting and leakages that may render the overall social spending less effective in promoting inclusive growth. 
In sum, the above exercise points to the ability of economic policy to influence how the benefits of growth are distributed across the income distribution. Of course, the results should be interpreted with caution. As in most macro-level analyses that lack exogenous variation, it is only possible to identify conditional correlations, rather than causal relationships. Additionally, there could be unobserved, state-specific time varying factors that affect both the pattern of growth and the policies or outcomes we identify. Yet, indicative evidence suggests that promoting financial development, providing higher education and making labor markets more flexible, increases the ability of the poor to gain from the growth process. Improving infrastructure may also lead to a growth process that is more inclusive of the poor.

\section{Conclusion}

While many have celebrated India's accelerating economic growth, others have expressed concern about the distributional impacts of the growth process. Cognizant of the vulnerability of its large population below the poverty line, India's authorities have made faster and more inclusive economic growth the primary goal of their development strategy (Planning Commission of India, 2006).

Decades of rapid growth have led to a dramatic reduction in poverty in rural and urban India, with millions of households escaping from poverty, and similarly dramatic declines in measured poverty depth. There is every reason to believe that economic growth will continue to lead to declines in poverty.

However, as India adopted a market-oriented model of development, there was a marked shift in the way the benefits of growth were distributed across the income distribution. In the 1980s, the growth rate of consumption of the bottom of the income distribution was substantially higher than that of the top. In contrast, in the 1990s, the top of the population enjoyed a substantially larger share of the gains from economic growth compared to the previous decade. This had significant effects on income inequality, which grew within states, across states, and between rural and urban areas.

To gain insight on why the inclusiveness of growth changed, we compare experiences across Indian states and over time. We find indicative evidence of the importance of economic policy. States with higher financial development, higher share of educated population and more flexible labor markets, raised the ability of the poor to gain from the growth process. Improving infrastructure may also lead to a growth process that is more inclusive of the poor.

Should the government be concerned that inequality is increasing? It is certainly true that the entire population, rich and poor alike, are significantly better off now than ten or twenty years ago. What are the costs or benefits associated with higher inequality?

Providing a definitive answer to this question is beyond the scope of this paper. Nevertheless, it may be useful to consider the characterization of Chaudhari and Ravallion (2006), who argue 
that there are two types of inequality. "Bad inequalities" are those that prevent individuals from connecting to markets, and limit investment and accumulation of human and physical capital, such as geographic poverty traps, patterns of social exclusion, lack of access to credit and insurance, etc. "Bad inequalities" are typically rooted in market and government failures. "Good inequalities," on the other hand, reflect the role of economic incentives. Widening income gaps, arising from an increase in the skill premium, increases the incentive for investment in education and may eventually narrow over time as the factor supply responds and younger generations invest more in their human capital (Becker and Murphy, 2007). Thus, the focus of policy makers should be on how to increase access to and quality of schooling and other social services, ease bottlenecks for participation of the poor in economic activities and remove potential sources of "bad inequalities." 


\section{APPENDIX I: DATA SOURCES}

State-level income data. National state domestic product (in real and nominal terms) is derived from the Economic and Political Weekly States database and Central Statistics Office. The data also provides a breakdown of the gross state domestic product into broad industrial categories: i.e., agriculture, industry (manufacturing and mining) and services.

Household level data. We use the $1983\left(38^{\text {th }}\right), 1987 / 88\left(43^{\text {th }}\right), 1993 / 94\left(50^{\text {th }}\right)$ and $2004 / 05\left(61^{\text {st }}\right)$ rounds of the National Sample Survey, Schedule 1 and Schedule 10. Monthly per capita consumption (in Schedule 1) were deflated using the officially provided deflators by the Planning Commission (Consumer Price Index for Agricultural Labor (CPIAL) for the rural sector and Consumer Price Index for Industrial Workers (CPIIW)) to be comparable across states, over time and across urban and rural areas. Poverty rates and poverty depth were also constructed using the official Planning Commission poverty lines. Daily wages were constructed from weekly time disposition questionnaire in Schedule 10 for 15-65 year adults engaged in work activities as regular salaried/wage employee and casual wage labor and were deflated in the same manner as monthly per capita consumption.

Population counts. We use information on state population from the World Bank's Fiscal Database, the primary source for which is the Central Statistical Organization of India.

Credit. Total credit of Scheduled Commercial Banks utilized by state is from the RBI Basic Statistical Tables, "State-Wise Classification of Outstanding Credit of Scheduled Commercial Banks according to Place of Sanction and Utilization."

Labor regulation. State labor regulation indicators are from Besley and Burgess (2004), updated using the Handbook of Industrial Law (Malik, 2002), and indicate whether a state has a pro-employer, pro-worker, or neutral labor market regulation based on amendments to the 1947 Industrial Disputes Act.

Education. The percentage of the total state population with completed primary education and above, and completed secondary education and above, is from the 1981, 1991, and 2001 Census of India. To construct annual series, we linearly interpolate the number of people in each educational group.

Infrastructure. The infrastructure indicator is constructed as the main factor from a principal component analysis of installed electricity capacity per capita, kilometers of surfaced roads per state area, and share of households with access to drinking water. Annual data on installed electricity capacity and kilometers of surfaced roads are from Purfield (2007). The primary source for statistics on roads is various issues of Basic Road Statistics of India. Access to drinking water is from the Economic Survey of India 2005/06, Table 95. Annual series for access to drinking water were completed by linearly interpolating the existing data. 
State social spending. State spending on social services is derived from the World Bank's States Fiscal Database, the primary source for which is the Reserve Bank of India's Annual Report on State Finances. 


\section{REFERENCES}

Ahluwalia, M., 2002, "State-Level Performance under Economic Reforms," in Economic Policy Reforms and the Indian Economy, ed. Anne Krueger (New Delhi: Oxford University Press).

Ahsan, A., and C. Pages, 2007, “Are All Labor Regulations Equal? Assessing the Effects of Job Security, Labor Dispute and Contract Labor Laws in India," World Bank Policy Research Working Paper 4259, June (Washington: World Bank).

Ahya, C., and M. Sheth, 2007, "India Economics. Globalization, Capitalism and Inequality." Morgan Stanley Research, June 14.

Aiyar, S., 2001, "Growth Theory and Convergence across Indian States," in India at the Crossroads: Sustaining Growth and Reducing Poverty, ed. Tim Callen, Patricia Reynolds and Christopher Towe (Washington: International Monetary Fund), pp. 143-69.

Banerjee, A., and E. Duflo, 2003, "Inequality and Growth: What Can the Data Say?" Journal of Economic Growth, 8, pp. 267-299.

and T. Piketty, 2005, “Top Indian Incomes, 1922-2000.” World Bank Economic Review, 19(1), pp. 1-20.

Bajpai, N., and J. Sachs, 1996, “Trends in Inter-State Inequalities of Income in India,” Harvard Institute for International Development, Development Discussion Paper No. 528 (Cambridge, Massachusetts: Harvard University).

Becker, G., and K. Murphy, 2007, “The Upside of Income Inequality,” American.com, (June).

Besley, T., and R. Burgess, 2003, "Halving Global Poverty," Journal of Economic Perspectives, 17(3), pp. 3-22.

— 2004, “Can Labor Regulation Hinder Economic Performance? Evidence from India," Quarterly Journal of Economics, 119(1), pp. 91-134.

and B. Esteve-Volart, 2007, "The Policy Origins of Poverty and Growth in India." in Delivering on the Promise of Pro-Poor Growth. Insights and Lessons from Country Experiences, eds. Timothy Besley and Louise Cord (New York: World Bank).

Bhalla, S. 2003, "Not as Poor, Nor as Unequal, as You Think-Poverty, Inequality and Growth in India, 1950-2000," Available via the Internet: http://www.oxusresearch.com/economic.asp 
Bhanumurthy, N. R., and A. Mitra, 2004, "Economic Growth, Poverty and Inequality in Indian States in the Pre-reform and Reform Periods," Asian Development Review, 21(2), pp. 79-99.

Bhattacharjea, Aditya, 2006, "Labour Market Regulation and Industrial Performance in India: A Critical Review of the Empirical Evidence," Indian Journal of Labour Economics, 29(2).

Bhattacharya, B., and S. Sakthivel, 2004, "Regional Growth and Disparity in India: Comparison of Pre- and Post Reform Decades," Economic and Political Weekly, 39(10), (March 6-12), pp. 1071-77.

Burgess, R., and R. Pande, 2005, "Do Rural Banks Matter? Evidence from the Indian Social Banking Experiment,” American Economic Review 95, pp. 780-95.

Chaudhuri, S., and M. Ravallion, 2006, "Partially Awakened Giants: Uneven Growth in China and India," in Dancing with Giants: China, India and the Global Economy, ed. L. Alan Winters and Shahid Yusuf (Washington: World Bank).

Datt, G., and M. Ravallion, 1992, "Growth and Redistributive Components of Changes in Poverty Measures: A Decomposition with Applications to Brazil and India in 1980s." Journal of Development Economics, 38, pp. 275-295.

- 2002, “Is India’s Economic Growth Leaving the Poor Behind?” Journal of Economic Perspectives, 16(3), pp. 89-108.

Deaton, A., 2003, "Prices and Poverty in India, 1987-2000." Economic and Political Weekly, (January), pp. 362-368.

, and J. Dreze, 2002, "Poverty and Inequality in India: A Re-examination,” mimeo, Princeton University.

Delong, B., 2004, "India since Independence: An Analytical Growth Narrative," in In Search of Prosperity: Analytical Narratives on Economic Growth, ed. Dani Rodrik.

Dhongde, S. 2007, "Measuring the Impact of Growth and Income Distribution on Poverty in India," forthcoming Journal of Income Distribution, 16(2).

Esteve-Volart, Berta, 2004, "Gender Discrimination and Growth: Theory and Evidence from India.” Development Discussion Paper 42, London School of Economics.

Gupta, P., R. Hasan, and U. Kumar, 2007, "What Constrains Indian Manufacturing?” mimeo, (New Delhi: Delhi School of Economics).

Hasan, R., D. Mitra, and K. V. Ramaswamy, 2003, “Trade Reforms, Labor Regulations and Labor Demand Elasticities: Evidence from India." forthcoming in the Review of 
Economics and Statistics, NBER Working Paper No. 9879 (Cambridge, Massachusetts: MIT Press).

Jain, L., and S. Tendulkar, 1990, "Role of Growth and Distribution in the Observed Change of the Headcount Ratio Measure of Poverty: a Decomposition Exercise for India," Technical Report no. 9004 (Delhi: Indian Statistical Institute).

Jayadev, A., S. Motiram, V. Vakulabharanam, 2007, "Patterns of Wealth Disparities in India During the Liberalization Era," Economic and Political Weekly, (September), pp. 3853-3863.

Kakwani, N., and K. Subbarao, 1990, "Rural Poverty and Its Alleviation in India," Economic and Political Weekly, (March 31), A2-A16.

Kochhar, K., U. Kumar, R. Rajan, A. Subramanian, and I. Tokatlidis, 2006, "India's Pattern of Development: What Happened, What Follows?"

Malik, P.L., 2003, Industrial Law (Lucknow: Eastern Book Company).

Planning Commission of India, 2006, "Towards Faster and More Inclusive Growth: An Approach to the Eleventh Five Year Plan (2007-2012)," Government of India.

Purfield, C., 2006, "Mind the Gap-Is Economic Growth in India Leaving Some States Behind?” IMF Working Paper 06/103 (Washington: International Monetary Fund).

Purfield, C., 2007, "India: Asset Prices and the Macroeconomy," IMF Working Paper 07/221 (Washington: International Monetary Fund).

Ravallion, M., 2001, “Growth, Inequality and Poverty,” World Development, 29(11), pp. 1803-1815.

, and G. Datt, 1996, "How Important to India's Poor is the Sectoral Composition of Economic Growth?" World Bank Economic Review, 10(1), pp. 1-25. , and S. Chen, 2003, "Measuring Pro-Poor Growth," Economic Letters 78, pp. 93-99.

Rodrik, D. and A. Subramanian, 2004, "From 'Hindu Growth' to Productivity Surge: The Mystery of the Indian Growth Transition," IMF Staff Papers.

Sundaram, K. and S. Tendulkar, 2001, "NAS-NSS Estimates of Private Consumption for Poverty Estimation," Economic and Political Weekly, (January 13-20).

Tilak, J., 2007, "Inclusive Growth and Education: On the Approach to the Eleventh Plan," Economic and Political Weekly, pp. 3872-3877, (September). 
Trivedi, K., 2002, "Educational Human Capital and Levels of Income: Evidence from States in India, 1965-92,” Working Paper, No. 97 (University of Oxford). 